\title{
Regulation of villin by Wnt5a/Ror2 signaling in human intestinal cells
}

\author{
Rebecca Cheung ${ }^{1,2}$, Jacqueline Kelly $y^{1,2}$ and R. John Macleod ${ }^{1,2,3 *}$ \\ ${ }^{1}$ Department of Physiology, Queen's University, Kingston, ON, Canada \\ 2 Gastrointestinal Disease Research Unit, Department of Medicine, Kingston General Hospital, Kingston, ON, Canada \\ ${ }^{3}$ Canada Research Chair (Tier 2) in Gastrointestinal Cell Physiology, Queen's University, Kingston, ON, Canada
}

\section{Edited by:}

Kenneth R. Hallows, University of

Pittsburgh School of Medicine, USA

\section{Reviewed by:}

Vivek Bhalla, Stanford University

School of Medicine, USA

Alexander Staruschenko, Medical

College of Wisconsin, USA

*Correspondence:

R. John Macleod, Canada Research Chair in Gastrointestinal Cell

Physiology, Department of

Biomedical and Molecular Sciences,

Room 3-003-4 (GIDRU/KGH),

76 Stuart Street, Queen's University,

Kingston, ON, Canada K7L 3N6.

e-mail: rjm5@queensu.ca
Regulation of expression of the intestinal epithelial actin-binding protein, villin, is poorly understood. The aim of this study was to determine whether Wnt5a stimulates Ror2 in intestinal epithelia caused transient increases in phospho-ERK1/2 (pERK1/2) and subsequently increased expression of villin transcript and protein. To demonstrate Wnt5a-Ror2 regulation of villin expression, we overexpressed wild-type, truncated, or mutant Ror2 constructs in HT29 adenocarcinoma cells and non-transformed fetally derived human intestinal epithelial cells, added conditioned media containing Wnt5a and measured changes in ERK1/2 phosphorylation, villin amplicons, and protein expression by RT-PCR and Western blot techniques. Wnt5a addition caused a transient increase in pERK1/2, which was maxi$\mathrm{mal}$ at $10 \mathrm{~min}$ but extinguished by $30 \mathrm{~min}$. Transient transfection with a siRNA duplex against Ror2 diminished Ror2 amplicons and protein and reduced the extent of pERK1/2 activation. Structure-function analysis revealed that the deletion of the cysteine-rich, kringle, or tyrosine kinase domain or substitution mutations of tyrosine residues in the intracellular Ser/Thr-1 region of Ror2 prevented the Wnt5a stimulation of $\mathrm{pERK} 1 / 2$. Deletion of the intracellular proline and serine/threonine-rich regions of Ror2 had no effect on Wnt5a stimulation of $\mathrm{pERK} 1 / 2$. The increase in villin expression was blocked by pharmacological inhibition of MEK-1 and casein kinase 1, but not by PKC and p38 inhibitors. Neither Wnt3a nor epidermal growth factor addition caused increases in villin protein. Our findings suggest that Wnt5a/Ror2 signaling can regulate villin expression in the intestine.

Keywords: villin, Wnt signaling, extracellular calcium sensing receptor, Ror2

\section{INTRODUCTION}

The molecular determinants of villin production in the intestine are largely unknown. Villin is a $92.5-\mathrm{kDa}$, actin-binding cytoskeletal protein which associates with the apex and axial bundle structures of intestinal microvilli to mediate cytoskeletal organization in the intestine (Coluccio and Bretscher, 1989; George et al., 2007). Studies have shown that the knock down of endogenous villin expression in intestinal epithelial cells induced low rates of brush border assembly (Costa de Beauregard et al., 1995; Pinson et al., 1998). Consequently, elucidating mechanisms which regulate villin expression in vitro could enhance understanding of determinants which mediate normal epithelial development in the gut.

In the adult small intestine, villin protein expression is detected along the entire crypt-villus axis, with levels of villin protein expression enhanced toward the villus tip (Maunoury et al., 1992). Ror2, a tyrosine kinase receptor, is the receptor for Wnt5a. Ror2 is expressed in murine small intestinal epithelia along the entire crypt-villus axis (Pacheco and MacLeod, 2008). Activation of the extracellular calcium sensing receptor (CaSR) increased Wnt5a secretion from colonic myofibroblasts. CaSR activation increased Ror2 expression on the epithelia. This paracrine Wnt5a/Ror2 signaling in intestinal epithelial cells led to the activation of the caudal type homeobox transcription factor 2 (CDX2), and sucrase-isomaltase (Pacheco and MacLeod, 2008) suggestive of increased epithelial differentiation. Wnt5a/Ror2 stimulates non-canonical Wnt signaling while Wnt3a activates the canonical Wnt/ $\beta$-catenin dependent pathway (Mikels and Nusse, 2006). Villin is regarded a marker for differentiated epithelial cells because of its distinctive expression gradient along the villus-crypt axis (Khurana and George, 2008). It is not known if Wnt5a/Ror2 signaling influences villin expression.

In H. pylori infected gastric cells, the villin promoter has been shown to be increased by Elk-1, a downstream nuclear transcription factor which is activated by ERK $1 / 2$ phosphorylation (Rieder et al., 2005). This suggested to us that the activation of ERK1/2 might, in the appropriate conditions, influence villin expression in intestinal epithelia. As described herein, we observed that Wnt5a added to non-transformed fetally derived intestinal cells or HT29 adenocarcinoma cells, when Ror2 was overexpressed, increased villin transcript and protein expression. We show that this effect required the cysteine-rich, kringle, and tyrosine kinase domain(s) of Ror2. The Wnt5a stimulation of pERK1/2 and villin expression occurred using Ror2 constructs lacking the proline and serine/threonine-rich regions of the intracellular tail (BDB Ror2). Mutations of tyrosine residues in the serine/threonine-1 
rich region of Ror2 (5YF Ror2) prevented Wnt5a stimulation of transient ERK1/2 phosphorylation and subsequent villin expression. This is the first demonstration that Wnt5a activating the BDB Ror2 signals differently than when Wnt5a interacts with 5YF Ror2. Addition of Wnt3a or epidermal growth factor (EGF) did not result in villin expression in the presence of wild-type Ror2 overexpression. Together, our results define a causal relationship of Wnt5a/Ror2 signaling in intestinal epithelial cells to transiently increase $\mathrm{pERK} 1 / 2$ and lead to villin protein expression.

\section{MATERIALS AND METHODS MATERIALS}

Inhibitors such as PD 098059 (MEK-1 inhibitor), SB 203580 (a p38 MAPK inhibitor), Bisindolylmaleimide I (inhibitor of PKC isotypes: $-\alpha,-\beta,-\gamma,-\delta,-\varepsilon$ ), and D4476 (a casein kinase I inhibitor) were purchased from EMD Calbiochem-Novabiochem (San Diego, CA, USA). Other investigations have demonstrated that at the following concentrations: $10 \mu \mathrm{M}$ PD 098059 (Alessi et al., 1995; Aliaga et al., 1999), 10 M SB 203580 (Clerk et al., 1998; Zhou et al., 2005; Tu and Perdue, 2006), $1 \mu \mathrm{M}$ Bisindolylmaleimide I (Toullec et al., 1991; Vayro and Silverman, 1999), and 100 MM D4476 (Rena et al., 2004; Bryja et al., 2007), ERK MAPK, p38 MAPK, PKC and CK1 and inhibited, respectively, in a variety of cell lines.

\section{CELL CULTURE}

The human colorectal adenocarcinoma HT29 cell line and mouse L-cells were purchased from American Tissue and Cell Culture (Rockville, MD, USA). Fetally derived, non-transformed, human intestinal epithelial cells (HIEC) were obtained from Dr. Boudreau (University de Sherbrooke, Sherbrooke, QC, Canada). The HT29 and L-cells were grown in Dulbecco's modified eagle media (DMEM) supplemented with 10\% fetal bovine serum (FBS), and 0.05\% Penstrep (all purchased from Invitrogen, Carlsbad, CA, USA). The non-transformed fetal HIECs were cultured in OPTI-MEM supplemented with 4\% FBS (Invitrogen), $0.05 \%$ L-glutamine (Invitrogen), 0.02\% EGF (Sigma, Oakville ON, Canada), and $0.05 \%$ HEPES (BioShop, Burlington, ON, Canada).

All cells were maintained at $37^{\circ} \mathrm{C}$, in $95 \%$ air, $5 \% \mathrm{CO}_{2}$ atmospheric conditions. HT29 cells and HIECs were passaged every 4-5 days, with 0.25 and $0.05 \%$ Trypsin (Invitrogen, Carlsbad, CA, USA), respectively. Only HT29 cells passaged within the first 6 weeks of initial thawing and passage 16-22 HIECs were used. Early passage cells were used to prevent spontaneous differentiation and transformation that is often observed in late-passage carcinoma-derived intestinal epithelial cell lines (Pinto et al., 1983; Vachon and Beaulieu, 1992).

\section{PREPARATION OF Wnt5a CONDITIONED MEDIA}

Mouse L-cells, stably transfected with Wnt5a plasmid, were seeded on $10 \mathrm{~cm}$ plates and supplemented with $10 \%$ DMEM, as previously described. After $24 \mathrm{~h}$, cells were then incubated in $0.5 \mathrm{mM}$ $\mathrm{Ca}^{2+}$ DMEM containing 0.1\% L-glutamine and 0.05\% Penstrep and supplemented with $0.2 \%$ bovine serum albumin. This media was collected 48 and $96 \mathrm{~h}$ afterward. Upon collection, media was centrifuged at $1000 \mathrm{RPM}$ for $5 \mathrm{~min}$ and the remaining supernatant was isolated, divided into aliquots, and kept at $-30^{\circ} \mathrm{C}$ for later use.

\section{TRANSIENT TRANSFECTIONS}

All DNA plasmid transfections completed for subsequent Western blot analysis and RT-PCR were performed using the Superfect transfection reagent, according to the manufacturer's instructions (Qiagen, Mississauga, ON, Canada). The wild-type Ror2 plasmid (WT Ror2) and Ror2 constructs containing deletions of: the cysteine-rich domain, aa $170-300$ ( $\triangle$ CRD Ror2); the kringle domain, aa $316-395$ ( $\Delta \mathrm{K}$ Ror2); regions including and distal to the tyrosine kinase domain, aa 502-944 ( $\Delta \mathrm{RS}$ Ror2); regions including and distal to the tail of tyrosine kinase domain, aa 749-944 (BDB Ror2), and a Ror2 construct containing substitutions of phenylalanine for five tyrosine residues in the first serine/threonine-rich domain, tyrosines $818,824,830,833,838$ (5YF Ror2) were generous gifts from Y. Minami (Kobe University, Kobe, Japan). The described constructs are summarized in Figure 1A. Expression levels of WT Ror2, $\Delta \mathrm{K}$ Ror2, $\Delta \mathrm{RS}$ Ror2, BDB Ror2, and 5YF Ror2 in HT29 cells are shown in Figure 1B. The expression of RS and BDB were higher then the wild-type Ror2 (1.8 $\times$ and $2.8 \times$, respectively) while expression of the $\Delta \mathrm{K}$ Ror 2 and $5 Y F$ Ror 2 were consistently lower $(0.30 \times$ and $0.26 \times$, respectively) then wild-type Ror2. The short-interfering RNA duplex pool against Ror2 (siRNA ${ }^{\text {Ror2 }}$ ) was comprised of four target sequences: 5'-GUCAUCGCUUGCCUGUUC-3', 5'ACCAACCCUUGAGCAUGA- $3^{\prime}, 5^{\prime}$-GCAAUGUGCUGGUGUAC GA-3', 5'-GAACCGGACUAUUUAUGUG-3' and was purchased from Dharmacon (Hornby, ON, Canada).

\section{WESTERN BLOT ANALYSIS}

HT29 cells and HIECs were seeded on 6-well plates; $24 \mathrm{~h}$ later, these cells were transfected with $2.0 \mu \mathrm{g}$ of a Ror 2 plasmid construct (as previously described) or with $200 \mathrm{nM}$ of siRNA ${ }^{\text {Ror2 }}$ (previously described) using Superfect (Qiagen), according to manufacturer's instructions. The plates were serum starved in $0.5 \mathrm{mM}$ $\mathrm{Ca}^{2+}$ DMEM supplemented with $0.2 \%$ BSA, 0.1\% L-glutamine and $0.05 \%$ Penstrep, as described previously. After $18 \mathrm{~h}$ of serum starvation, the cells were incubated with Wnt5a conditioned media for $0,2,5,10,30,60 \mathrm{~min}$. Following incubation, cells were rinsed once with ice-cold PBS containing $1 \mathrm{mM}$ sodium orthovanadate and $25 \mathrm{mM}$ sodium fluoride. Cells were subsequently lysed in $20 \mathrm{mM}$ Tris- $\mathrm{HCl}$, ph 7.4, $150 \mathrm{mM} \mathrm{NaCl}, 1 \mathrm{mM}$ EDTA, $1 \mathrm{mM}$ EGTA, 25 mM NaF, 1\% Triton X-100, 10\% glycerol, 1 mM dithiothreitol, $1 \mathrm{mM}$ sodium orthovanadate, and a cocktail of protease inhibitors containing $10 \mu \mathrm{M}$ each of pepstatin, soybean trypsin inhibitor, leupeptin, aprotinin, calmodulin.

Lysates $(40-60 \mu \mathrm{g}$ total protein) were loaded onto an $8 \%$ (for villin immunoblotting), $10 \%$ (for pERK1/2 or ERK1/2 immunoblotting), or $12 \%$ (for Ror2 or FLAG-tag, NDYKDDDDK-C, immunoblotting) Bisacrylamide gel. Proteins were transferred electrophoretically onto a polyvinylidene difluoride (PDVF) membrane (Millipore, Bedford, MA, USA). Following transfer, membranes were blocked for $1 \mathrm{~h}$ in $5 \%$ milk in $1 \times$ Tris Buffered Saline and 0.1\% Tween-20 $(1 \times$ TBS-T). To detect expression of phosphorylated-ERK1/2 (pERK1/2), total amounts of ERK1/2 (ERK1/2), Ror2, FLAG-tag, and villin protein, membranes were incubated with a polyclonal rabbit antibody specific for pERK1/2, ERK1/2, Ror2, FLAG-tag, or villin in 1XTBS-T with $5 \%$ BSA in a 1:1000 dilution (antibodies purchased from Cell 
A

VT-ROR2

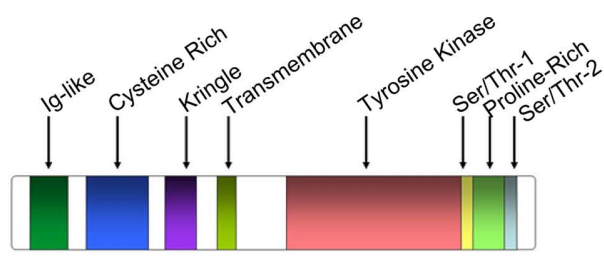

$\triangle \mathrm{CRD}-\mathrm{ROR} 2$

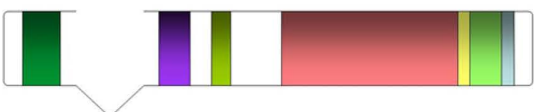

$\triangle \mathrm{K}-\mathrm{ROR} 2$

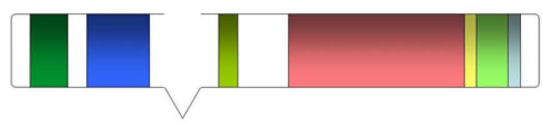

RS-ROR2

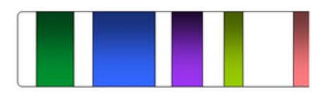

5YF-ROR2

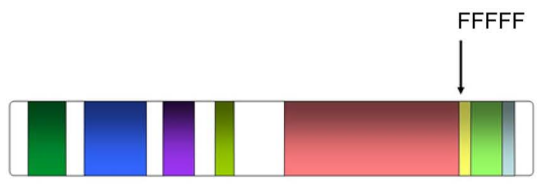

BDB-ROR2

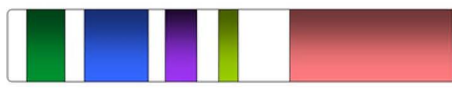

B

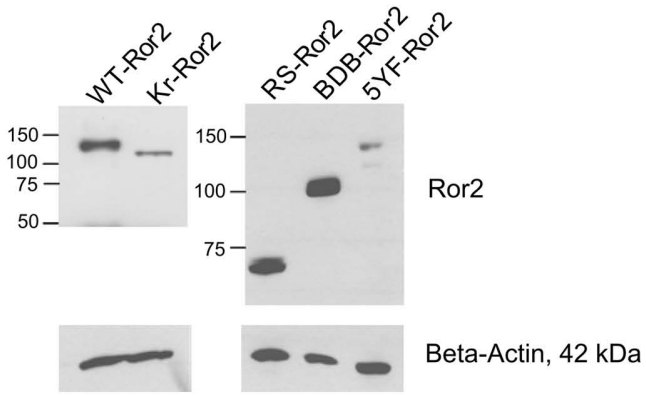

FIGURE 1 | (A) Schematic representation of the Ror2 constructs used in these experiments. Full length Ror2 is characterized by three extracellular domains (lg-like, cysteine-rich and kringle domains), as well as four conserved intracellular domains (tyrosine kinase, serine/threonine-rich-1, proline-rich, serine/threonine-rich-2 domains). The various Ror2 constructs are characterized by deletions of specific putative domains of Ror2. The $\triangle \mathrm{CRD}$ Ror2 contains a deletion of the cysteine-rich domain. In the $\triangle \mathrm{K}$ Ror2 construct, the kringle domain has been truncated. In RS Ror2, a majority of the tyrosine kinase domain, as well as regions distal to this domain have been deleted. The 5YF Ror2 construct contains five substitution mutations in the Ser/Thr-1 region, where five tyrosine residues have been replaced by phenylalanines. The BDB Ror2 construct contains a deletion of the Ser/Thr-1, proline, and Ser/Thr-2 rich regions. (B) Expression levels of WT Ror2, $\Delta K$, $\mathrm{RS}, \mathrm{BDB}$, and $5 \mathrm{YF}$ in HT29 cells with beta-actin as a loading control.

Signaling Technology Inc., Danvers, MA, USA). Membranes were left at $4^{\circ} \mathrm{C}$, shaking overnight. To detect $\beta$-actin protein expression, membranes were incubated with a mouse antibody specific for $\beta$-actin (Sigma, St Louis, MO, USA) diluted to 1:10000 in 1XTBS$\mathrm{T}$, under similar conditions and incubated with an anti-rabbit or anti-mouse secondary conjugated to horseradish peroxidase (Sigma, St Louis, MO, USA) in 1XTBS-T containing 5\% milk for $1 \mathrm{~h}$. Protein bands were visualized by incubating the membrane with luminol and peroxide substrates from a commercially purchased chemiluminescence kit (SuperSignal, Pierce Chemical; Rockford, IL, USA).

\section{REVERSE TRANSCRIPTASE-POLYMERASE CHAIN REACTION}

A two-step RT-PCR for villin was performed to assess for differential gene expression. RNA was extracted from Wnt5achallenged, Ror2-overexpressing HT29 cells and non-transformed fetal HIECs. RNA was isolated using TRIzol, according to manufacturer's instructions (Invitrogen).

cDNA synthesis was performed from total RNA using the Omniscript reverse transcription kit as per manufacturer's instructions (Qiagen; Mississauga, ON, Canada). Total 1.0 $\mu \mathrm{g}$ of cDNA, from the resulting cDNA synthesis, was combined with the appropriate primers for human villin along with a reverse-transcriptase enzyme, Taq Polymerase (from a purchased Reverse-Transcriptase kit by Qiagen; Mississauga, ON, Canada). Primers for villin are sense $5^{\prime}$-TAG CTG TGG TTG TAA AGC AGT ACC-3' and antisense $5^{\prime}$-GGT ATC ATC TTT CTG AAG GAA TAG G-3'. The PCR cycle parameters were as follows: an initial $60 \mathrm{~s}$ initial denaturation period at $104^{\circ} \mathrm{C} ; 30$ amplification cycles consisting of a 30 -s-denaturation period at $104^{\circ} \mathrm{C}$; a 30 -s-annealing period at $55^{\circ} \mathrm{C}$, and a 1 -min elongation period at $72^{\circ} \mathrm{C}$; a final 10 -min elongation period at $72^{\circ} \mathrm{C}$. The resulting PCR product was loaded onto a $1 \%$ agarose gel and visualized by UV light. The sequence of the RT-PCR product from the described experiment was: $5^{\prime}$ CGATATTAGTCCTACACCAATTGAAGTGAAATTTTGCAGATG TGCCTATGAGCACAAACTTCTGTGGCAAATGCCAGTTTTGT TTAATAATGTACCTATTCCTCAGAAAGATGATA-3'.

\section{DENSITOMETRY}

Densitometry was performed on X-rays of developed Western blot experiments. The densities of individual bands were measured using ImageJ (version $1.40 \mathrm{~g}$ ). Measured experimental densities were normalized against the density of the appropriate loading control. These corrected densities were normalized to the most intense band in the given experiment.

\section{STATISTICS}

Data are presented as means $\pm \mathrm{SE}$ of at least three separate experiments. Student's $t$-tests were performed on data, where appropriate. Statistical significance was defined as: $P<0.05$.

\section{RESULTS}

\section{Wnt5a INTERACTION WITH Ror2 STIMULATED ERK1/2} PHOSPHORYLATION IN ADENOCARCINOMA-DERIVED HT29 CELLS

We first determined whether Wnt5a and Ror2 would stimulate the ERK1/2 (p44/42) MAPK cascade in adenocarcinoma-derived HT29 intestinal epithelial cells (Figure 2). ERK1/2 activation is characterized by dual phosphorylation of both the ERK1 and ERK2 (p44 and p42) isotypes. Approximately $24 \mathrm{~h}$ after seeding on 6-well plates, cells were transfected with $2.0 \mu \mathrm{g}$ of (full length) WT Ror2 DNA plasmid, and subsequently challenged with Wnt5a conditioned media (Wnt5a CM) for 0, 2, 5, 10, 30, 60 min (along with 


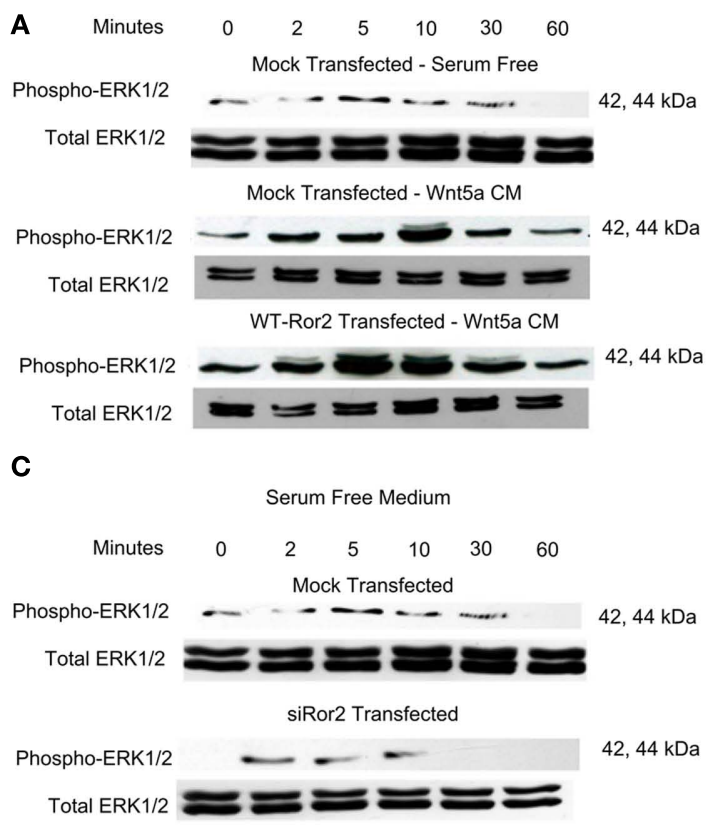

FIGURE 2 |Wnt5a stimulation of Ror2 induced ERK 1/2 (p44 and p42) phosphorylation in HT29 cells. (A) HT29 cells were grown in DMEM supplemented with $10 \%$ FBS, transfected with WT Ror2 or no plasmid. Cells were serum starved for $18 \mathrm{~h}$. Cells were challenged with Wnt5a CM for 0, 2, $5,10,30,60 \mathrm{~min}$. Western blot analysis screening for total (phosphorylated and unphosphorylated) ERK1/2 expression was included as loading control.
B

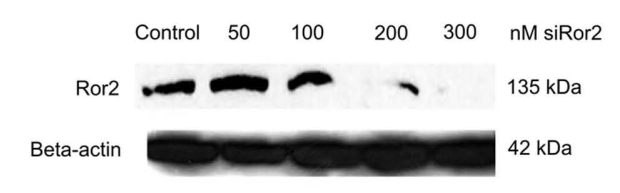

D

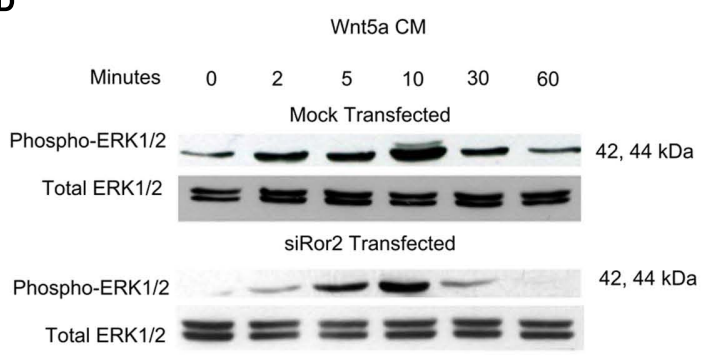

(B) HT29 cells were transiently transfected with either 0, 50, 100, 200, and $300 \mathrm{nM}$ siRNA ${ }^{\text {Ror2 } 2}$ and blotted for Ror2. (C,D) HT9 cells were transfected with either siRNARor2 or no plasmid in the presence (D) or absence of Wnt5a CM for the time points listed above. Western immunoblotting for total ERK1/2 was included as an internal loading control. Blots shown are representative of three separate experiments with similar results. a negative control lacking plasmid). It was determined that levels of both p44 and p42 phosphorylation transiently and robustly increased between 2 and 30 min of Wnt5a CM treatment. Maximal ERK1 and 2 phosphorylation occurred at 5-10 min, before diminishing to baseline levels at $60 \mathrm{~min}$ (Figure 2A, bottom panel). In contrast, in mock-transfected HT29 cells, which were Wnt5achallenged in a similar manner, levels of ERK1/2 phosphorylation were substantially attenuated; dual-ERK1/2 phosphorylation was observed only at $10 \mathrm{~min}$ (Figure $2 \mathrm{~A}$, middle panel).

To verify whether the Ror2 receptor is a necessary mediator of Wnt5a-induced ERK1/2 activation, we completed experiments employing the use of a short-interfering RNA duplex aimed specifically against the Ror2 ( siRNA $\left.^{\text {Ror2 }}\right)$. We have shown that in response to increasing transfection concentrations of siRNA ${ }^{\text {Ror2 }}$ in HT29 cells, Ror 2 receptor expression was dose-dependently downregulated (Figure 2B). At $200 \mathrm{nM}$ concentrations of siRNA ${ }^{\text {Ror2}}$, immunoreactive Ror2 expression was barely detectable in cell lysates; we used this concentration of siRNA ${ }^{\text {Ror2 }}$ for subsequent experiments.

Because ERK1/2 is an extracellular signal-regulated MAPK, and may be activated by a diverse set of agonists including cytokines, growth factors, and serum elements, we elected to determine whether the serum elements in the medium alone were sufficient to induce robust increases in ERK1/2 phosphorylation in these cells. Through Western blot analysis screening for phosphorylated ERK1 and 2 (pERK1/2), low levels of pERK2 were observed in cells where Ror2 receptor expression had been silenced and subsequently treated with minimum serum $(0.2 \% \mathrm{BSA})$ media, which does not contain Wnt5a (Figure 2C, bottom panel), or where cells had been mock-transfected, and treated in a similar manner (Figure 2C; top panel).

We went on to compare ERK1/2 phosphorylation in HT29 cells, which had been transfected with WT Ror2 or siRNA ${ }^{\text {Ror2 }}$ and subsequently treated with Wnt5a CM. As previously shown, we observed that in WT Ror2-transfected cells, Wnt5a challenge induced a transient increase in dual-ERK1/2 phosphorylation (Figure 2A, bottom panel). However, upon similar challenge with Wnt5a CM in siRor2-transfected cells, ERK1/2 phosphorylation was attenuated (Figure 2D). The ERK1/2 phosphorylation was restricted to the ERK2 (p42) isotype.

From these experiments, we conclude that activation of both ERK1/2 (p44/p42) occurred transiently in response to Wnt5a addition to Ror2-overexpressing epithelial cells. Furthermore, these findings suggest that medium change or knocking down expression of Ror2 have a comparable effect - stimulating p42 activation exclusively. We therefore elected to use the transient activation of both p44 and p42 as the index of ERK1/2 phosphorylation.

\section{Wnt5a-ACTIVATION OF ERK1/2 INDUCED VILLIN PROTEIN EXPRESSION IN ADENOCARCINOMA CELLS}

Earlier studies using gastric cancer cells have reported that activation of the ERK1/2 MAPK cascade can induce Elk-1 mediated villin promoter activity (Rieder et al., 2005). Because Elk-1 is activated by phosphorylated ERK1/2, we went on to determine whether Wnt5a-Ror2 induced ERK1/2 activation would enhance villin expression in HT29 cells. We assessed villin expression by RT-PCR 
and Western analysis, on HT29 cells overexpressing Ror2 and challenged with Wnt5a CM for 18 or $24 \mathrm{~h}$, respectively. Using the BLAST algorithm, this sequence was shown to be $100 \%$ homologous with human villin mRNA. In cells that were mock-transfected and/or left untreated, basal levels of villin transcript expression were low. In contrast, when WT Ror2-overexpressing cells were challenged with Wnt5a CM for $24 \mathrm{~h}$, levels of villin amplicon were substantially upregulated. This upregulated villin transcript expression was lost in the presence of PD $098059(10 \mu \mathrm{M})$, a specific MEK-1 inhibitor, which is directly upstream of the ERK1/2 MAPK cascade (Figure 3A).

There was a noticeable increase in villin protein production in WT Ror2-overexpressing cells challenged with Wnt5a $\mathrm{CM}$ for $24 \mathrm{~h}$. In contrast, villin protein expression was low in mock-transfected and/or untreated cells (Figure 3B). Again, this increased villin protein expression was lost in similarly treated WT Ror2-overexpressing cells, in the presence of PD 098059 (10 $\mu \mathrm{M}$; Figure 3B).

To assess whether other intracellular effectors could be involved in Wnt5a-stimulated villin protein production, we screened for immunoreactive villin in cells treated with inhibitors of PKC and p38 MAPK. Again, we observed low levels of villin protein in untreated or mock-transfected HT29 cells. Upon Wnt5a CM challenge in WT Ror2-overexpressing cells, villin protein production was noticeably increased. In the presence of Bisindolylmaleimide I ( $1 \mu \mathrm{M}$; an inhibitor of PKC- $\alpha,-\beta,-\gamma,-\delta,-\varepsilon)$, and SB203580 (10 $\mu \mathrm{M}$; a specific inhibitor of all p38 isotypes), levels of villin protein production remained increased in Wnt5a CM-challenged Ror2-overexpressing cells. Addition of D4476 (100 $\mu \mathrm{M}$; a CKI inhibitor) prevented Wnt5a-induced villin expression in WT Ror2-expressing cells (Figure 3C). Taken together, these results suggest that Wnt5a-Ror2 induced ERK1/2 activation, which enhanced villin protein production in HT29 cells. This Wnt5a-induced ERK1/2 phosphorylation also required CKI involvement. However, PKC and p38 MAPK did not appear to mediate this effect.

\section{Wnt5a-INDUCED ERK1/2 ACTIVATION AND SUBSEOUENT VILLIN PROTEIN PRODUCTION REQUIRED SPECIFIC FUNCTIONAL REGIONS OF Ror2}

Having established Ror2 functionality in mediating Wnt5a's induction of ERK1/2, we went on to elucidate the specific regions of the receptor necessary in mediating this affect. To verify which domains of Ror2 are necessary for induction of ERK1/2 phosphorylation, we completed further Wnt5a time course experiments, assessing ERK1/2 phosphorylation via Western blot analysis, in HT29 cells overexpressing truncated or mutated Ror 2 constructs. A set of control cells, which overexpress WT Ror2, were run concurrently with each experiment. Both experimental and control cells were treated with Wnt5a CM for 0, 2, 5, 10, 30, and $60 \mathrm{~min}$. Experimental and control lysates were run concurrently on acrylamide gels and transferred onto PDVF membranes within the same apparatus and exposed on the same piece of film to ensure consistency. In cells expressing a Ror2 receptor where the cysteine-rich domain has been truncated ( $\triangle \mathrm{CRD}$ Ror2), or the kringle domain has been deleted ( $\Delta K$ Ror2), or a majority of the tyrosine kinase domain and regions distal to this domain have been deleted (RS Ror2), or where five tyrosine residues of the serine/threonine-1 domain had been substituted with phenylalanines (5YF Ror2), levels of Wnt5a-induced ERK1/2 phosphorylation were substantially attenuated compared to WT Ror2-transfected cells (Figures 4A-D).

In contrast, in cells expressing a BDB Ror2 receptor, where only the distal proline and serine/threonine-rich regions of the receptor had been deleted, levels of both ERK1/2 (p44 and p42) robustly increased over the course of an hour. The pattern of Wnt5ainduced ERK1/2 phosphorylation in these BDB Ror2-expressing cells was similar to that of control WT Ror2-transfected cells (Figure 4E).

Densitometry confirmed that the intensity of ERK1/2 phosphorylation in WT Ror2-transfected control cells incubated with Wnt5a CM for 10 min was significantly increased compared to baseline. Additionally, the degree of ERK1/2 phosphorylation was significantly greater in Wnt5a-challenged WT Ror2 HT29 cells compared to similarly treated cells expressing $\triangle \mathrm{CRD}, \Delta \mathrm{K}, \mathrm{RS}$, or 5YF Ror2 (Figures 4A-D). Densitometry on three separate ERK1/2 time course experiments confirmed that the degree and pattern of ERK1/2 activation in Wnt5a-treated BDB Ror2-cells resembled that of similarly treated control cells (Figure 4E, right panel). Expression levels of WT, $\triangle \mathrm{K}, \mathrm{RS}, \mathrm{BDB}$, and 5YF Ror2 constructs is shown in Figure 1B. We note that overexpression of $\mathrm{RS}$ and $\mathrm{BDB}$ relative to WT Ror2 generated opposite effects on ERK1/2 phosphorylation, while reduced expression of $\Delta K$ and 5 YF relative to WT Ror2 generated comparable effects on ERK1/2 phosphorylation.

We then assessed levels of villin protein production in HT29 cells transfected with a Ror2 receptor where the cysteine-rich domain has been deleted ( $\triangle \mathrm{CRD}$ Ror2), five tyrosine residues on the Ser/Thr-1 domain had been substitution-mutated (5YF Ror2), or where the proline/serine rich regions of the receptor had been deleted (BDB Ror2). Immunoblotting for villin demonstrated that in mock-transfected or unchallenged WT Ror2-expressing cells, levels of villin protein production were low. However, in WT Ror2-overexpressing cells challenged with Wnt5a CM for $24 \mathrm{~h}$, levels of villin protein production were increased. In contrast, in $\triangle$ CRD Ror2 and 5YF Ror2-overexpressing cells, treatment with Wnt5a CM did not enhance villin protein production (Figure 5A). However, in cells where the proline and serine/threonine-rich domains of the Ror2 receptor had been deleted (BDB Ror2), upon Wnt5a challenge, levels of villin protein production were increased (Figure 5B).

Consistent with previous findings, our work suggested that the extracellular cysteine-rich domain is a necessary component of Wnt5a-induced ERK1/2 activation and subsequent villin protein production. Additionally, these experiments also show that despite the fact that both $5 \mathrm{YF}$ and BDB Ror2 rendered the Ser/Thr-1 domain of the receptor inactive, either by mutation or deletion, respectively, these Ror 2 constructs signaled in a different manner. It appears that the expression of the tyrosine residues in the Ser/Thr-1 was necessary for Wnt5a's interaction with full length Ror2 to stimulate ERK1/2. However, deletion of regions including and distal to Ser/Thr-1 did not affect Wnt5a stimulation of ERK1/2 and subsequent increases in villin protein. 
A

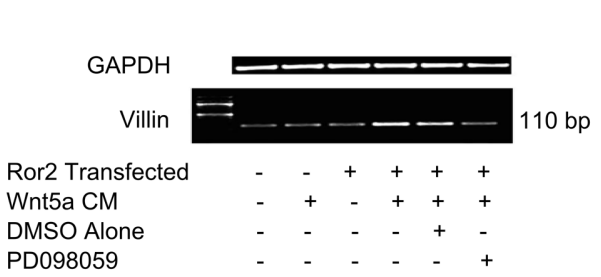

B

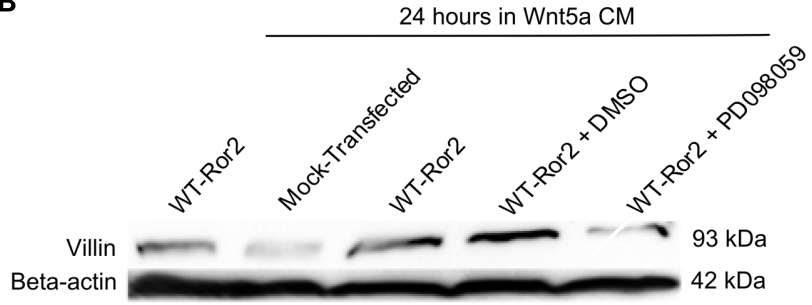

C

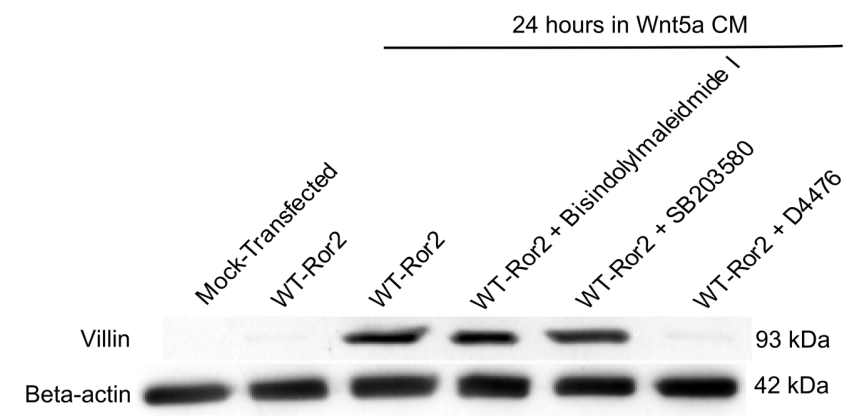

FIGURE 3 |Wnt5a interaction with Ror2 upregulated villin transcript and increased protein expression via an ERK1/2-dependent mechanism. (A) HT29 cells were transfected with Ror2 (no plasmid as control) and treated with Wnt5a and/or PD 098059 (1 $\mu \mathrm{M}$ ), DMSO (as shown in legend). RT-PCR analysis for Villin (GAPDH as control) was performed. (B) Villin protein expression was upregulated in WT Ror2-transfected cells treated with Wnt5a conditioned media for $24 \mathrm{~h}$, compared to mock-transfected and/or untreated cells. In the presence of a specific MEK-1 inhibitor (PD 098059; $1 \mu \mathrm{M}$ ), the increased villin protein expression was lost. Western blotting for $\beta$-actin was performed as an internal loading control. (C) Inhibitors of PKC (Bisindolylmaleimide I; $1 \mu \mathrm{M}$ ) and p38 (SB 203580; $1 \mu \mathrm{M}$ ) did not, but a CKI inhibitor (D4476; $100 \mu \mathrm{M}$ ) did prevent Wnt5a-induced villin protein increases. Immunoreactive villin, at levels similar to that of Wnt5a-treated WT Ror2-transfected HT29 control cells, were detected in cells treated in a similar manner in the presence of a Bisindolylmaleimide I and SB 203580. Wnt5a-stimulated villin protein was prevented with the addition of D4476. Screening for immunoreactive $\beta$-actin in cell lysates was conducted to show equal loading. These Western blots are representative of three individually performed experiments.
RECOMBINANT Wnt5a, BUT NEITHER Wnt3a NOR EGF, STIMULATED VILLIN PROTEIN PRODUCTION IN ADENOCARCINOMA-DERIVED CELLS

To determine whether other forms of Wnt5a or other Wnt family members, besides Wnt5a, could stimulate villin protein production in HT29 cells, we challenged WT Ror2-overexpressing cells with recombinant mouse Wnt5a (rWnt5a) and recombinant mouse Wnt3a (rWnt3a), and assessed for villin protein production. In mock-transfected cells treated with Wnt5a CM, levels of villin protein were low, as observed in previous experiments. Upon addition of either Wnt5a conditioned media or rWnt5a $(200 \mathrm{ng} / \mathrm{mL})$ for $24 \mathrm{~h}$ in Ror2-overexpressing cells, levels of villin protein were increased. Following similar addition of rWnt3a (200 ng/mL) to WT Ror2-transfected cells, villin protein production was not increased (Figure 6A).

To determine whether other ERK1/2 agonists could induce increased villin production, we stimulated cells with EGF. EGF is a well-characterized activator of the ERK1/2 cascade. Western blot analysis screening for pERK1/2 confirmed that EGF (100 nM) stimulated transient and robust increases in dual-ERK1/2 (both p44/p42) phosphorylation between 2 and $30 \mathrm{~min}$ of incubation (Figure 6B). Upon immunoblotting for villin protein, we found, as with previous experiments, that the levels of villin protein expression in unchallenged or mock-transfected cells were not increased. In contrast, in WT Ror2-transfected cells challenged with Wnt5a CM for $24 \mathrm{~h}$, villin protein expression was noticeably increased, within the same experiment. However, in WT Ror2transfected cells treated with EGF for a similar $24 \mathrm{~h}$ time period, immunoreactive villin was low (Figure 6C).

From these experiments, we conclude that both Wnt5a CM and recombinant Wnt5a treatment stimulated villin protein production. However, treatment with either another Wnt family member, Wnt3a, or a separate ERK1/2 agonist, EGF, did not induce enhanced villin production.

\section{Wnt5a-INDUCED ERK1/2-DEPENDENT VILLIN PROTEIN PRODUCTION IN Ror2-TRANSFECTED FETALLY DERIVED NON-TRANSFORMED HUMAN INTESTINAL EPITHELIAL CELLS}

From our previous experiments, we observed that adenocarcinomaderived HT29 cells expressed increasing basal levels of villin protein with passage. Thus, we elected to repeat similar experiments in fetally derived non-transformed human intestinal epithelial (HIECs), which normally express very little or no villin protein.

To assess whether villin protein production is stimulated by Wnt5a-Ror2 in fetal non-transformed HIECs, we completed immunoblotting for villin in cells overexpressing the Ror2 receptor and had been challenged with Wnt5a CM for $24 \mathrm{~h}$. As seen in previous experiments, in unchallenged and mock-transfected cells, levels of villin protein were low. In Ror2-overexpressing cells, 


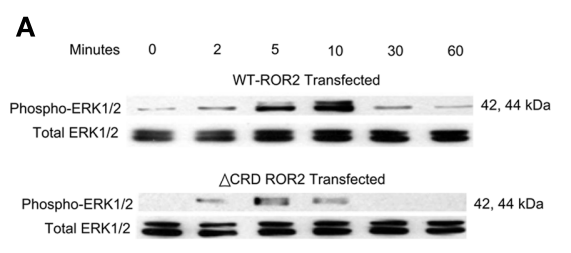

B

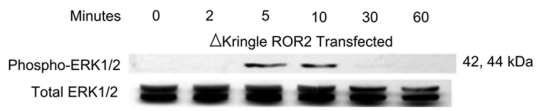

C

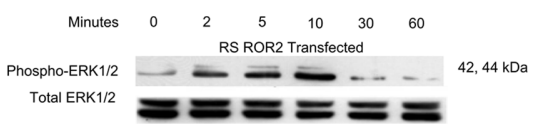

D

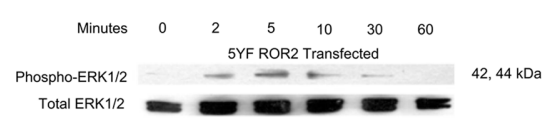

$\mathbf{E}$

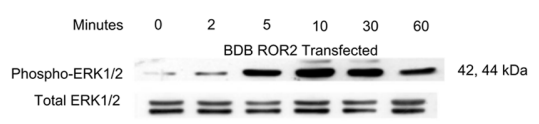

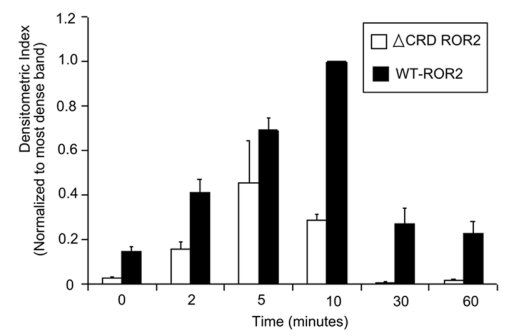
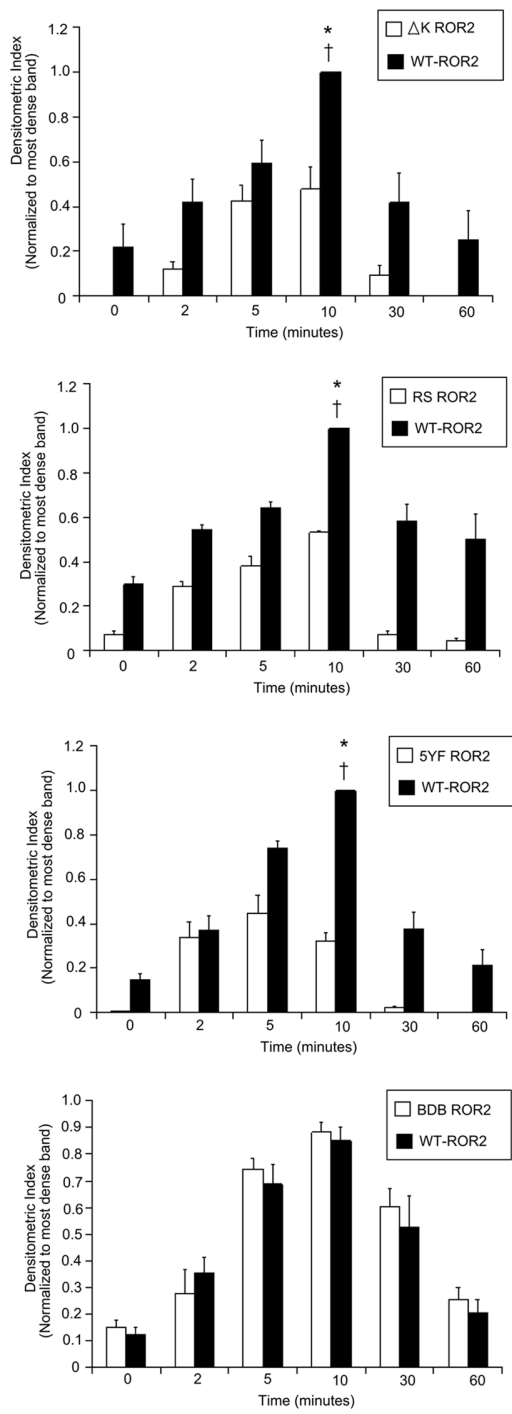

an internal loading control. The blots discussed are representative of three separate experiments with similar results. (A-E) Right panels:

densitometry confirmed that maximal ERK $1 / 2$ phosphorylation in Wnt5a-challenged WT Ror2 control cells consistently occurred at $10 \mathrm{~min}$. Additionally, maximal ERK1/2 phosphorylation was significantly more intense compared to baseline and compared to ERK1/2 phosphorylation in similarly treated cells expressing a truncated or mutated Ror2. (E) Right panel: the pattern and degree of ERK $1 / 2$ phosphorylation was conserved in BDB Ror2-transfected cells challenged with Wnt5a. Results are expressed as means $\pm \mathrm{SD}$ of three independently performed experiments. ${ }^{*} P<0.05$ compared to $10 \mathrm{~min}$ of Wnt5a CM incubation in truncated or mutant Ror2-transfected cells. ${ }^{\mathrm{tP}}<0.05$ compared to 0 min of Wnt5a incubation in WT Ror2-transfected cells. 


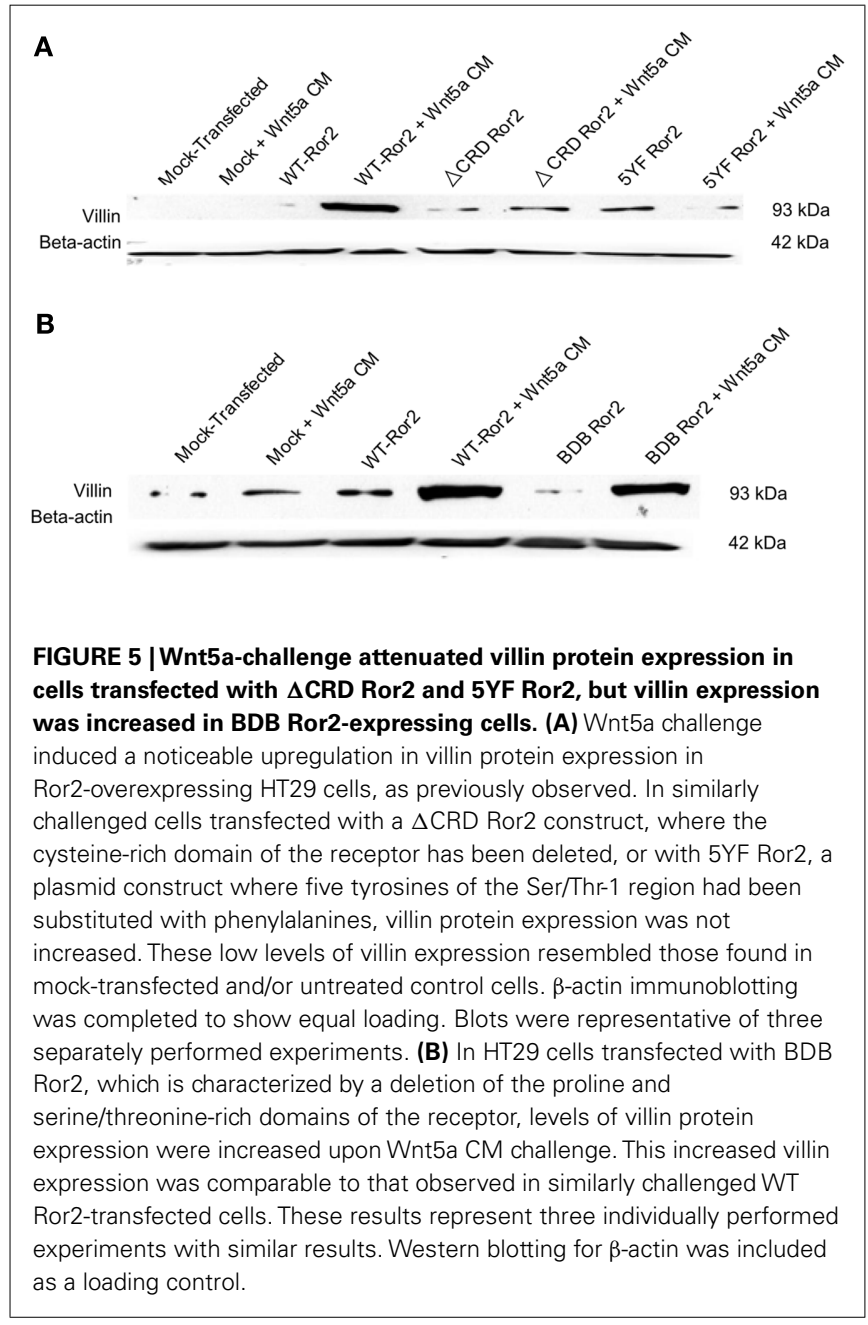

without Wnt5a stimulation, there was a slight increase in villin expression. With Wnt5a addition to WT Ror2-overexpressing cells, there was a noticeable increase in villin protein production (Figure 7).

To assess if this Wnt5a-induction of villin was ERK1/2mediated, we challenged WT Ror2-overexpressing fetal-derived non-transformed HIECs with Wnt5a CM for $0,2,5,10$, and $60 \mathrm{~min}$ and measured levels of ERK1/2 phosphorylation. We found that there was a transient and robust increase in dual-ERK1/2 phosphorylation over the course of an hour. Maximal ERK1/2 phosphorylation occurred between 5 and $10 \mathrm{~min}$ (Figure 7B). This pattern of ERK1/2 phosphorylation resembled that of similarly challenged WT Ror2-overexpressing HT29 cells (Figure 2C).

To determine which intracellular signaling cascades mediated this Wnt5a-stimulated villin production, we challenged WT Ror2-expressing cells with Wnt5a CM in presence of MEK-1 inhibitor (10 $\mu \mathrm{M}$; PD 098059), Bisindolylmaleimide I ( $1 \mu \mathrm{M}$; an inhibitor of PKC $-\alpha,-\beta,-\gamma,-\delta,-\varepsilon)$, SB $203580(10 \mu \mathrm{M}$; a specific inhibitor of all p38 isotypes), and D4476 (100 $\mu \mathrm{M}$; an inhibitor of CKI isotypes), and assessed for levels of villin protein. In the presence of either PD 098059 or D4476, levels of villin protein were not increased upon Wnt5a addition (Figures 7C,D).

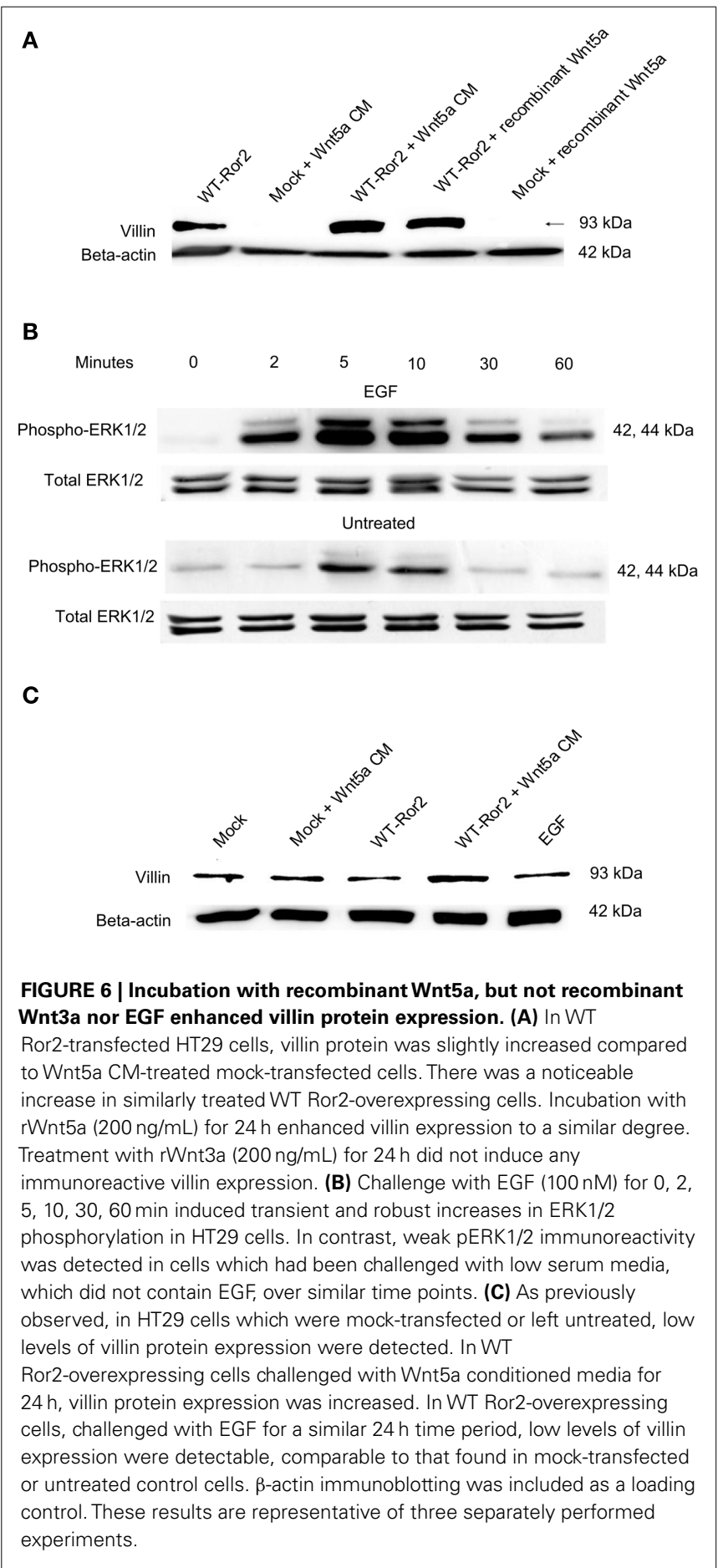

However, incubation with Bisindolylmaleimide I or SB 203580 did not prevent the Wnt5a-stimulated increases in villin protein (Figure 7D).

From these experiments, we conclude that villin protein expression is enhanced upon WT Ror2 overexpression but villin expression was further increased with Wnt5a treatment. This Wnt5a-stimulated villin protein was likely mediated by an ERK1/2 MAPK cascade and/or by casein kinase I. 
A

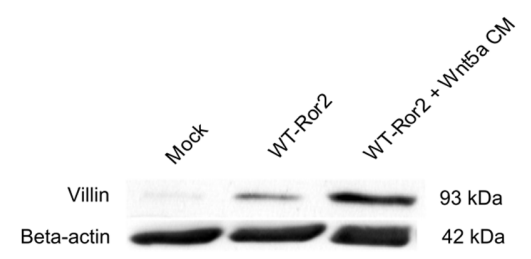

C

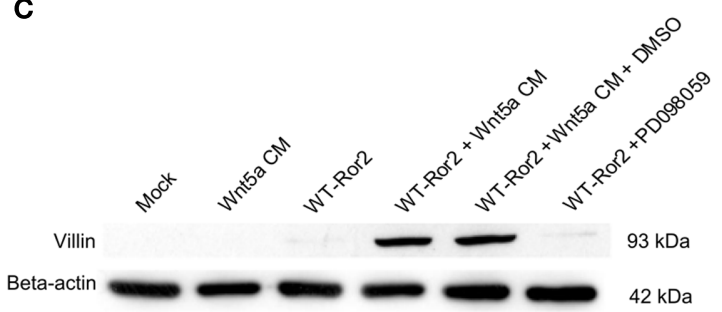

FIGURE 7 |Wnt5a challenge stimulated villin expression, via an ERK1/2-dependent mechanism in WT Ror2-overexpressing human intestinal epithelial cells (HIECs). (A) Villin protein was barely detectable in mock-transfected and/or unchallenged HIECs. Upon Wnt5a treatment, levels of villin transcript expression were slightly increased. Overexpression of WT Ror2 in these cells induced faint villin expression. Treating WT Ror2-cells with Wnt5a CM for $24 \mathrm{~h}$ noticeably enhanced villin protein expression. (B) Wnt5a addition in Ror2-overexpressing cells transiently and robustly increased dual-ERK1/2 phosphorylation over the course of an hour. (C) The
B

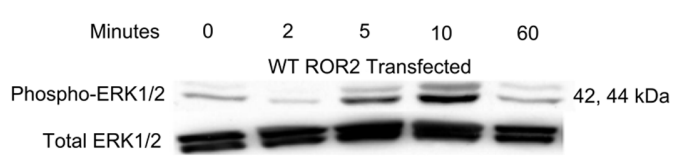

D

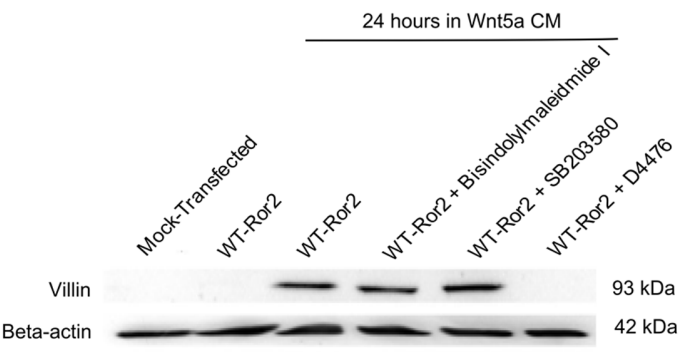

Wnt5a-enhanced villin protein expression was prevented in similarly treated cells, in the presence of PD 098059 (10 $\mu$ M). (D) However, increased villin protein levels were maintained in Wnt5a-challenged WT Ror2-cells, despite the presence of either Bisindolylmaleimide I $(1 \mu \mathrm{M})$ or SB $203580(10 \mu \mathrm{M})$. Yet, in the presence of D4476 $(100 \mu \mathrm{M})$, Wnt5a-induced villin protein expression was prevented For all experiments described, Western blotting for immunoreactive $\beta$-actin was performed to demonstrate equal loading. These experiments reflect results from similar experiments performed separately.

\section{THE Ser/Thr-1 DOMAIN OF THE Ror2 RECEPTOR DIFFERENTIALLY MEDIATED VILLIN PROTEIN PRODUCTION IN HIECS}

To determine which regions of the Ror2 receptor were necessary to mediate Wnt5a-induced villin protein production in fetal nontransformed HIECs, we completed Western blotting for villin in lysates collected from Wnt5a-treated cells where five critical tyrosine residues in the serine/threonine-1 region of Ror2 had been substituted with phenylalanine (5YF Ror2) or where the proline and serine/threonine-rich regions of the receptor had been deleted (BDB Ror2; Figure 8A). As previously observed, in unchallenged WT Ror2 (control) cells, we found low, but detectable levels of villin protein expression. Upon Wnt5a treatment in WT Ror2overexpressing cells, levels of villin protein were increased. In contrast, in both untreated or Wnt5a CM-challenged 5YF Ror2transfected cells, immunoreactive villin protein was undetectable. In untreated BDB Ror2-expressing cells, we observed low levels of immunoreactive villin protein, comparable to levels seen in untreated WT Ror2-transfected HIECs. In Wnt5a-challenged BDB Ror2-overexpressing cells, the amount of villin protein was increased, comparable to that seen in similarly challenged WT Ror2-overexpressing cells. The results from these experiments were consistent with data collected from previous experiments in HT29 cells (Figures 5A,B). Though both 5YF Ror2 and BDB Ror2 eliminated tyrosine phosphorylation in the Ser/Thr1 domain, upon Wnt5a treatment, these mutant/truncated Ror2 constructs signaled in a different manner. The tyrosine phosphorylation in Ser/Thr-1 domain was necessary in full length Ror2 but not in a truncated version Ror2 where the regions including, and distal to, the Ser/Thr-1 region were eliminated.
Thus, in both transformed (HT29 cells) and fetally derived nontransformed (HIECs) human intestinal epithelial, Wnt5a signaled differently in 5YF mutations compared with the BDB deletions of Ror2.

\section{Wnt3a DID NOT ENHANCE VILLIN PROTEIN PRODUCTION IN NON-TRANSFORMED HUMAN INTESTINAL EPITHELIAL CELLS}

To determine whether another Wnt family member (Wnt3a) or another ERK1/2 agonist (EGF) would stimulate villin protein production in fetally derived non-transformed HIECs, we treated cells with either rWnt3a or EGF and probed for immunoreactive villin. Consistent with previous experiments, in mock-transfected HIECs villin protein production was faint. Upon WT Ror2transfection, villin protein production was slightly increased. In Ror2-overexpressing cells challenged with Wnt5a CM for $24 \mathrm{~h}$, villin protein expression was substantially increased. However, when WT Ror2-transfected cells were challenged, similarly for $24 \mathrm{~h}$, with $\mathrm{rWnt} 3 \mathrm{a}$ protein $(200 \mathrm{ng} / \mathrm{mL})$, levels of villin protein production were unchanged, comparable to levels observed in untransfected and untreated control cells (Figure 8B).

\section{DISCUSSION}

The major findings from this study are summarized in the schematic (Figure 9). We found that Wnt5a/Ror2 signaling caused ERK1/2 activation and subsequent villin protein expression in HT29 adenocarcinoma cells and a fetally derived nontransformed human intestinal epithelial cell line. Evidence that Wnt5a-stimulated Ror2 to induce ERK1/2 activation was demonstrated by different experimental approaches. Western blotting for 


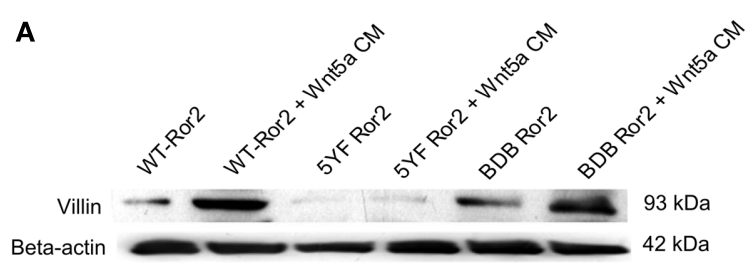

B

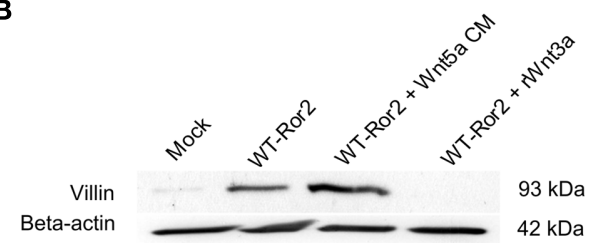

FIGURE 8 |Wnt5a treatment did not stimulate villin protein expression in 5YF Ror2-expressing HIECs but did induce villin protein expression in BDB Ror2-expressing HIECs. (A) In untreated WT Ror2-expressing cells, villin protein expression was not detectable; upon Wnt5a challenge for $24 \mathrm{~h}$, villin expression was substantially increased. Levels of villin protein were low in untreated and Wnt5a-treated 5YF Ror2-expressing cells. Similar Wnt5a treatment upregulated the amount of immunoreactive villin in cells transfected with BDB Ror2. $\beta$-actin immunoreactivity was assessed to confirm equivalent loading. These results are representative of three separate experiments. (B) Incubation with recombinant Wnt3a protein did not stimulate villin protein expression in Ror2-overexpressing HIECs. Villin protein expression was not detectable in untreated mock-transfected HIEC, but was slightly enhanced in untreated WT Ror2- expressing cells. Villin protein expression was noticeably increased with Wnt5a CM-challenge for $24 \mathrm{~h}$ in WT Ror2-overexpressing cells. In similarly transfected cells, rWnt3a incubation for a 24 -h period did not induce increases in villin protein. $\beta$-actin immunoreactivity was assessed to confirm equivalent loading. These results are representative of three separate experiments.

ERK1/2 showed that Wnt5a conditioned media treatment induced transient and robust increases in ERK1/2 phosphorylation in Ror2-overexpressing intestinal epithelial cells. Media change alone failed to stimulate ERK1/2 phosphorylation. Ror2 expression was a necessary component of Wnt5a-induced ERK1/2 activation, since when Ror2 expression was reduced by RNAi, this phosphorylation was attenuated. Results of structure-function studies suggested the requirement of the cysteine-rich, kringle, and tyrosine kinase domains of Ror2 for Wnt5a-mediated activation of the ERK1/2 MAPK cascade in these cells. Wnt5a addition did not stimulate ERK1/2 activation in cells which expressed a Ror2 receptor with five substitution-mutated tyrosines in the Ser/Thr-1 rich region (5YF Ror2). However, cells which expressed a Ror2 with the serine/threonine and proline-rich regions deleted (BDB Ror2), Wnt5a caused robust increases in ERK1/2 phosphorylation. We report that expression levels of these different Ror2 constructs in the endogenously Ror2-expressing HT29 cells varied. If our Wnt5a-stimulated ERK1/2 responses were dictated by differences in the expression levels it is difficult to understand how the robustly overexpressed RS-Ror2 generated a different response (inhibition of ERK1/2), compared with the BDB Ror2 (no inhibition). Indeed, even when expressed at a lower level compared with the WT Ror2, the $\Delta \mathrm{K}$ and $5 \mathrm{YF}$ constructs inhibited the Wnt5a-stimulated ERK1/2. Because both the 5YF and BDB Ror2 constructs eliminated tyrosine phosphorylation function in the Ser/Thr-1 domain,

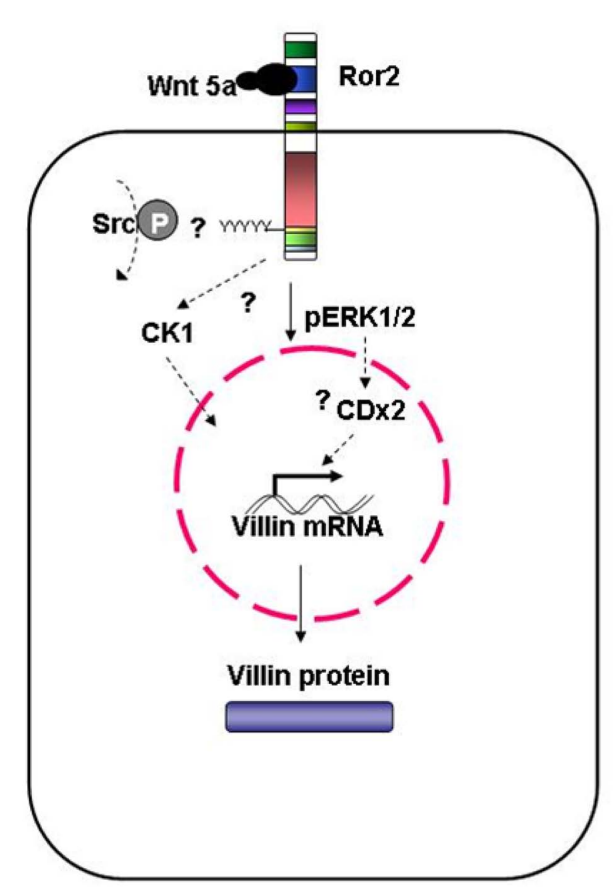

FIGURE 9 | Model of Wnt-induced villin protein expression in adenocarcinoma-derived HT29 cells and fetally derived, untransformed human intestinal epithelial cells. Wnt5a interaction with Ror2 is mediated by the cysteine-rich domain. Phosphorylation of the tyrosines within in the Ser/Thr-1 region, possibly by Src, induces ERK1/2 phosphorylation. Stimulated ERK1/2 upregulates villin transcript expression; this subsequently increases villin protein. This Wnt5a-induced villin expression is also mediated by CK1. As well, CDX2, acting downstream of, or in parallel with, the activated ERK1/2 MAPK cascade could be mediating Wnt5a-induced increases in villin protein.

we conclude that Wnt5a interacted with these constructs to signal differently pERK1/2 and increases in villin protein.

Villin protein was increased after Wnt5a-induced ERK1/2 activation in the two model cell lines. Villin protein expression was blocked in the presence of a specific inhibitor of MEK-1, an upstream mediator of the ERK1/2 MAPK signaling cascade, and in the presence of a casein kinase 1 (CK1) inhibitor, Wnt5a-enhanced villin expression was prevented. However, enhanced villin protein expression was not blocked in the presence of a general PKC or p38 inhibitor. These results suggested that non-canonical Wnt5aactivation of ERK1/2 was highly specific, as a canonical Wnt family member, Wnt3a, and EGF, a separate ERK1/2 agonist, failed to stimulate villin protein production. Together, these findings from a reductionistic system suggested Wnt5a/Ror2 signaling could regulate villin production in intestinal epithelia.

Wnt5a/Ror2 signaling is mediated through the functional domains of the Ror2 receptor. For instance, Wnt5a interaction with Ror2 expressed in HT29, HEK, L, H441, and A549 cells antagonized $\beta$-catenin TopFlash reporter activity (Mikels and Nusse, 2006; MacLeod et al., 2007; Li et al., 2008). These effects were mediated by the intracellular domain of the receptor (Mikels and Nusse, 2006; Abdullah et al., 2008). In contrast, Wnt1 challenge in human sarcoma cells stimulated the tyrosine kinase domain of 
Ror2 and subsequent $\beta$-catenin reporter activity (Billiard et al., 2005). The current report describes that Wnt5a/Ror2 activation stimulates an ERK1/2 MAPK cascade. Indeed, we have demonstrated that the cysteine-rich, kringle, and tyrosine kinase domains, and likely tyrosine phosphorylation within the serine/threonine-1 region, are involved in mediating the MAPK cascade and increases in villin.

In our experiments, we observed that Wnt5a-stimulated ERK1/2 phosphorylation in cells expressing BDB Ror2, but not in cells expressing a 5YF Ror2. Insight into the function of the C-terminus (Ser/Thr-1 and proline regions) of Ror2 has been generated in a study showing that the C-terminus was required for the recruitment of the non-receptor kinase Src (Akbarzadeh et al., 2008). Pharmacological inhibition of Src suppressed Ror2 activation (Akbarzadeh et al., 2008). One interpretation of these results was that the BDB Ror2 was defective in kinase activation via failure to recruit Src. Our current results showing 5YF Ror2 prevented pERK1/2 stimulation and villin protein increases, while BDB Ror2 had no effect, suggest to us that recruitment of Src and phosphorylation of the five tyrosines in the BDB region were a necessary and sufficient event for Wnt5a-activation of Ror2 to generate transient pERK1/2 stimulation leading to villin production. Clearly, Wnt5a interaction with 5YF Ror2 and BDB Ror2 was different. Further experiments are required to delineate how $\mathrm{Src}$ is mobilized by Wnt5a stimulation, as well as the role of Src in villin protein regulation. While it is known from in vitro experiments that Src tyrosine phosphorylated villin, leading to increased intestinal cell migration as well as a villin-mediated anti-apoptosis, these effects were observed in models of villin overexpression (Mathew et al., 2008). Our current experiments have focused on how Wnt5a interaction with Ror2 led to increases in villin. To date, we are unaware of studies which have compared the functions of 5YF Ror2 and BDB Ror2 following Wnt5a stimulation. While we know that 5YF Ror2 failed to phosphorylate G-protein receptor kinase-2 (GRK2) on tyrosine residues by ectopic expression of CK1 1 , those studies did not test whether or not BDB Ror2 stimulated GRK2 (Kani et al., 2004). In future studies, it will be important to understand how putative Src activation of the 5YF sites in the Ser/Thr-1 region alter function compared with the absence of the Ser/Thr-1 region altogether. Are other tyrosine sites in the intracellular domain Src phosphorylated in the regions deleted in BDB Ror2? We report that in these endogenously Ror2-expressing cells, the BDB and 5YF levels were not comparable. Indeed, there was more BDB and less 5 YF compared with the wild-type Ror2. If increased expression was a determinant of the Wnt5a-stimulated pERKs, then presumably both constructs would have behaved the same. They did not. Even when expressed at a lower level the 5YF construct blocked Wnt5a stimulation of pERK, while the greater level of BDB had no effect. Therefore, our current results strongly suggest that tyrosine phosphorylation, likely mediated by Src kinases, at sites within the proline-serine/threonine-rich regions of Ror2 are essential for ERK1/2 MAPK stimulation and villin protein production.

Earlier work has implicated ERK1/2 phosphorylation in stimulating intestinal epithelial differentiation (Houde et al., 2001). Indeed, others have shown in $H$. pylori - gastric cancer cells, that villin promoter activity is stimulated by Elk-1, a transcription factor which is downstream of the ERK MAPK cascade (Rieder et al., 2005). These studies were consistent with our findings that Wnt5a/Ror2 signaling will stimulate ERK1/2 phosphorylation. This event likely mediates villin protein production. We have shown that pharmacological inhibition of MEK-1 prevented Wnt5a-mediated increases in villin protein in two distinct epithelial model cell types. However, pharmacological inhibition of PKC isoforms $-\alpha,-\beta,-\gamma,-\delta,-\varepsilon$, and p38 MAPK isoforms had no effect on Wnt5a-induced villin protein expression in HT29 adenocarcinoma cells or in non-transformed fetal-derived human intestinal epithelia. Previous studies using Ror2 in heterologous cell lines have shown that Wnt5a stimulates JNK (Yamanaka et al., 2002) and GSK-3 $\beta$ (Yamamoto et al., 2008), while the receptors which mediate $\mathrm{p} 38, \mathrm{PKC}$, or $\mathrm{CK} 1 / 2$ following Wnt5a stimulation have not yet been identified.

Our current work is consistent with previous findings that CK1 mediates Wnt signaling in the intestine, as Wnt5a-induction of villin protein was prevented by pharmacological inhibition of CK1 (Bryja et al., 2007). Little is understood about the role of $\mathrm{CK} 1$ in the intestine. It is known that CK1 $1 \varepsilon$ abundance and activity increased in transmissible murine colonic hyperplasia, suggesting CK1 $1 \varepsilon$ modulated hyperproliferation in mouse epithelia (Umar et al., 2007). Such findings are consistent with CK1 as a positive regulator of $\mathrm{Wnt} / \beta$-catenin signaling. However, other studies have demonstrated that Wnt5a-mediated dopaminergic neuronal differentiation was blocked in the presence of D4476. However, the specific receptor mediating this effect was not investigated (Bryja et al., 2007). Our work is consistent with previous findings that CK1 mediates Wnt signaling in the intestine, as Wnt5a-induction of villin protein was prevented by pharmacological inhibition of CK1. In future experiments it will be important to understand if Wnt5a-mediated CK1 phosphorylation precedes or follows ERK1/2 activation, or does this signaling occur in parallel?

The villin promoter has CDX2 responsive sites (Yamamichi et al., 2009). Previously we reported Wnt5a/Ror2 signaling in HT29 and Caco-2 adenocarcinoma cells, profoundly increased both CDX2 transcript and protein leading to activation of a sucrase-isomaltase promoter. Addition of rhWnt5a to these cells caused a 15 -fold increase in CDX2 protein within $1 \mathrm{~h}$ which declined to threefold over basal level by $2 \mathrm{~h}$ (Pacheco and MacLeod, 2008). The determinants of CDX2 protein half-life are largely unknown, but phosphorylation by p38 MAP kinase has been reported to increase CDX2 half-life (Houde et al., 2001). Because the increase in CDX2 transcript and protein occurred at longer times compared with the activation of $\mathrm{pERK} 1 / 2$ described in the current studies, it may be that the Wnt5a stimulation of pERK1/2 is an important determinant of the upregulation of CDX2 transcript or the substantial increases in CDX2 protein. The current studies have not investigated whether Wnt5a-induction of CDX2 protein is a necessary determinant of the subsequent stimulation of villin. Further experiments are needed to reduce CDX2 increases and address whether the Ror2-stimulation of pERK1/2 is influenced and if villin transcript and protein changes have occurred. Indeed, because the current studies show that EGF caused the same transient stimulation of pERK1/2 in Ror2-overexpressing cells but did not cause an increase in villin protein, it will be important to know if EGF increases CDX2 in these cells. Alternatively it could be that while both CDX2 and Elk-1 can activate the villin promoter, 
either factor alone is sufficient for villin production. While we have shown that Wnt5a stimulation of Ror2 will increase CDX2, we do not know if this precedes or is in parallel with pERK1/2 activation. Our current evidence strongly supports, however, signaling of Wnt5a/Ror2 on intestinal epithelia stimulating pERK1/2 to increase villin transcript and protein.

We proposed that Wnt5a-Ror2 induction of ERK1/2 and villin requires CK1. We have observed in both non-transformed, fetally derived HIEC, and HT29 cells that Ror2 overexpression stimulates villin expression. This could likely be mediated by Ror2 homodimerization triggering kinase activity independently from Wnt5a. Several studies have shown that though Wnt5a addition induced activation of wild-type Ror2 kinase (Billiard et al., 2005; Akbarzadeh et al., 2008). Additionally, in the absence of Wnt5a, a constitutively dimerized form of Ror2 exhibited tyrosine kinase activity (Akbarzadeh et al., 2008; Liu et al., 2008). Our lab has previously reported that Ror2 is expressed in intestinal epithelia throughout the crypt-villus axis (Pacheco and MacLeod, 2008). Interestingly, Ror 2 and villin share similar expression profiles. Villin protein is also widely expressed in intestinal epithelia, though its expression is progressively increased as cells migrate toward the tip of the villi (Dudouet et al., 1987). Additionally, Ror2 and CDX2 also share similar expression profiles: both are localized

\section{REFERENCES}

Abdullah, H. I., Pedraza, P. L., McGiff, J. C., and Ferreri, N. R. (2008). CaR activation increases TNF production by mTAL cells via a Gi-dependent mechanism. Am. J. Physiol. Renal Physiol. 294, F345-F354.

Akbarzadeh, S., Wheldon, L. M., Sweet, S. M., Talma, S., Mardakheh, F. K., and Heath, J. K. (2008). The deleted in brachydactyly B domain of ROR2 is required for receptor activation by recruitment of Src. PLoS ONE 3, e1873. doi: 10.1371/journal.pone.0001873

Alessi, D. R., Cuenda, A., Ohen, P., Udley, D. T., and Altiel, A. R. (1995). PD 098059 is a specific inhibitor of the activation of mitogen-activated protein kinase kinase in vitro and in vivo. J. Biol. Chem. 270, 27489-27494.

Aliaga, J. C., Deschenes, C., Beaulieu, J. F., Calvo, E. L., and Rivard, N. (1999). Requirement of the MAP kinase cascade for cell cycle progression and differentiation of human intestinal cells. Am. J. Physiol. 277, G631-G641.

Billiard, J., Way, D. S., Seestaller-Wehr, L. M., Moran, R. A., Mangine, A., and Bodine, P. V. (2005). The orphan receptor tyrosine kinase Ror2 modulates canonical Wnt signaling in osteoblastic cells. Mol. Endocrinol. 19, 90-101.

Bryja, V., Schulte, G., Rawal, N., Grahn, A., and Arenas, E. (2007). Wnt-5a induces Dishevelled phosphorylation and dopaminergic differentiation via a CK1-dependent mechanism. J. Cell Sci. 120(Pt 4), 586-595.

Clerk, A., Michael, A., and Sugden, P. H. (1998). Stimulation of multiple mitogen-activated protein kinase sub-families by oxidative stress and phosphorylation of the small heat shock protein, HSP25/27, in neonatal ventricular myocytes. Biochem. J. 333(Pt 3), 581-589.

Coluccio, L. M., and Bretscher, A. (1989). Reassociation of microvillar core proteins: making a microvillar core in vitro. J. Cell Biol. 108, 495-502.

Costa de Beauregard, M. A., Pringault, E., Robine, S., and Louvard, D. (1995). Suppression of villin expression by antisense RNA impairs brush border assembly in polarized epithelial intestinal cells. EMBO J. 14, 409-421.

Dudouet, B., Robine, S., Huet, C., Sahuquillo-Merino, C., Blair, L., Coudrier, E., and Louvard, D. (1987). Changes in villin synthesis and subcellular distribution during intestinal differentiation of HT29-18 clones. J. Cell Biol. 105, 359-369.

George, S. P., Wang, Y., Mathew, S., Srinivasan, K., and Khurana, S. (2007). Dimerization and actin-bundling properties of villin and its role in the assembly of epithelial cell brush borders. J. Biol. Chem. 282, 26528-26541.

Houde, M., Laprise, P., Jean, D., Blais, M., Asselin, C., and Rivard,

to intestinal epithelia throughout the crypt-villus axis (Mallo et al., 1997). Use of transgenic floxed Ror2 mice are required to answer this question in vivo. Whether Ror2, alone or working as a coreceptor, induces villin expression in the intestine independent of Wnt5a is not known.

We conclude that Wnt5a/Ror2 signals to stimulate pERK1/2 and subsequent villin protein expression in adenocarcinomaderived intestinal HT29 cells and non-transformed, fetally derived HIEC. We have shown that Wnt5a signals differently in 5YF Ror2expressing cells compared to BDB Ror2-expressing cells, though both Ror2 constructs eliminate tyrosine phosphorylation in the Ser/Thr-1 regions. Additionally, we have demonstrated that CK1 is required for Wnt5a-induced villin protein expression. Together the current study demonstrates Wnt5a-mediated non-canonical signaling requiring Ror2 will regulate villin in intestinal epithelial cells.

\section{ACKNOWLEDGMENTS}

We acknowledge funding from the Crohn's and Colitis Foundation of Canada (CCFC), CIHR, and NSERC-Dairy Farmers of Canada. All Ror2 plasmids were a gift from Y. Minami (Kobe, Japan). R. John Macleod is supported through the Canada Research Chairs program.

N. (2001). Intestinal epithelial cell differentiation involves activation of p38 mitogen-activated protein kinase that regulates the homeobox transcription factor CDX2. J. Biol. Chem. 276, 21885-21894.

Kani, S., Oishi, I., Yamamoto, H., Yoda, A., Suzuki, H., Nomachi, A., Iozumi, K., Nishita, M., Kikuchi, A., Takumi, T., and Minami, Y. (2004). The receptor tyrosine kinase Ror2 associates with and is activated by casein kinase Iepsilon. J. Biol. Chem. 279, 50102-50109.

Khurana, S., and George, S. P. (2008). Regulation of cell structure and function by actin-binding proteins: villin's perspective. FEBS Lett. 582, 2128-2139.

Li, C., Chen, H., Hu, L., Xing, Y., Sasaki, T., Villosis, M. F., Li, J., Nishita, M., Minami, Y., and Minoo, P. (2008). Ror2 modulates the canonical Wnt signaling in lung epithelial cells through cooperation with Fzd2. BMC Mol. Biol. 9, 11. doi: 10.1186/1471-2199-9-11

Liu, Y., Rubin, B., Bodine, P. V., and Billiard, J. (2008). Wnt5a induces homodimerization and activation of Ror2 receptor tyrosine kinase. J. Cell. Biochem. 105, 497-502.

MacLeod, R. J., Hayes, M., and Pacheco, I. (2007). Wnt5a secretion stimulated by the extracellular calcium-sensing receptor inhibits defective Wnt signaling in colon cancer cells. Am. J. Physiol. Gastrointest. Liver Physiol. 293, G403-G411.
Mallo, G. V., Rechreche, H., Frigerio, J. M., Rocha, D., Zweibaum, A., Lacasa, M., Jordan, B. R., Dusetti, N. J., Dagorn, J. C., and Iovanna, J. L. (1997). Molecular cloning, sequencing and expression of the mRNA encoding human Cdx1 and Cdx2 homeobox. Downregulation of $\mathrm{Cdx} 1$ and $\mathrm{Cdx} 2$ mRNA expression during colorectal carcinogenesis. Int. J. Cancer 74, 35-44.

Mathew, S., George, S. P., Wang, Y., Siddiqui, M. R., Srinivasan, K., Tan, L., and Khurana, S. (2008). Potential molecular mechanism for c-Src kinase-mediated regulation of intestinal cell migration. J. Biol. Chem. 283, 22709-22722.

Maunoury, R., Robine, S., Pringault, E., Leonard, N., Gaillard, J. A., and Louvard, D. (1992). Developmental regulation of villin gene expression in the epithelial cell lineages of mouse digestive and urogenital tracts. Development 115 , 717-728.

Mikels, A. J., and Nusse, R. (2006). Purified Wnt5a protein activates or inhibits beta-catenin-TCF signaling depending on receptor context. PLoS Biol. 4, e115. doi: 10.1371/journal.pbio.0040115

Pacheco, I. I., and MacLeod, R. J. (2008). Extracellular calcium-sensing receptor (CaSR) stimulates secretion of Wnt5a from colonic myofibroblasts to stimulate CDX2 and sucrase isomaltase using Ror2 on intestinal 
epithelia. Am. J. Physiol. Gastrointest. Liver Physiol. 295, G748-G759.

Pinson, K. I., Dunbar, L., Samuelson, L., and Gumucio, D. L. (1998). Targeted disruption of the mouse villin gene does not impair the morphogenesis of microvilli. Dev. Dyn. 211, 109-121.

Pinto, M., Robine-Leon, S., Appay, M. D., Triadou, N., Dussaulx, E., Lacroix, B., Simon-Assmann, P., Haffen, K., Fogh, J., and Zweibaum, A. (1983). Enterocyte-like differentiation and polarization of the human colon carcinoma cell line Caco-2 in culture. Biol. Cell 47, 323-330.

Rena, G., Bain, J., Elliott, M., and Cohen, P. (2004). D4476, a cellpermanent inhibitor of CK1, suppresses the site-specific phosphorylation and nuclear exclusion of FOXO1a. EMBO Rep. 5, 60-65.

Rieder, G., Tessier, A. J., Qiao, X. T., Madison, B., Gumucio, D. L., Merchant, J. L. (2005). Helicobacterinduced intestinal metaplasia in the stomach correlates with Elk-1 and serum response factor induction of villin. J. Biol. Chem. 280, 4906-4912.
Toullec, D., Pianetti, P., Coste, H., Bellevergue, P., Grand-Perret, T., Ajakane, M., Baudet, V., Boissin, P., Boursier E., and Loriolle, F. (1991). The bisindolylmaleimide GF 109203X is a potent and selective inhibitor of protein kinase C. J. Biol. Chem. 266, 15771-15781.

Tu, Y., and Perdue, M. H. (2006). CD23mediated transport of IgE/immune complexes across human intestinal epithelium: role of p38 MAPK. Am. J. Physiol. Gastrointest. Liver Physiol. 291, G532-G538.

Umar, S., Wang, Y., Morris, A. P., and Sellin, J. H. (2007). Dual alterations in casein kinase I-epsilon and GSK-3beta modulate betacatenin stability in hyperproliferating colonic epithelia. Am. J. Physiol. Gastrointest. Liver Physiol. 292, G599-G607.

Vachon, P. H., and Beaulieu, J. F. (1992). Transient mosaic patterns of morphological and functional differentiation in the Caco2 cell line. Gastroenterology 103, 414-423.

Vayro, S., and Silverman, M. (1999). PKC regulates turnover rate of rabbit intestinal $\mathrm{Na}+$-glucose transporter expressed in COS-7 cells. Am. J. Physiol. 276(Pt 1), C1053-C1060.

Yamamichi, N., Inada, K., Furukawa, C., Sakurai, K., Tando, T., Ishizaka, A., Haraguchi, T., Mizutani, T., Fujishiro, M., Shimomura, R., Oka, M., Ichinose, M., Tsutsumi, Y., Omata, M., and Iba, H. (2009). Cdx2 and the Brm-type SWI/SNF complex cooperatively regulate villin expression in gastrointestinal cells. Exp. Cell Res. 315, 1779-1789.

Yamamoto, S., Nishimura, O., Misaki, K., Nishita, M., Minami, Y., Yonemura, S., Tarui, H., and Sasaki, H. (2008). Cthrcl selectively activates the planar cell polarity pathway of Wnt signaling by stabilizing the Wnt-receptor complex. Dev. Cell 15, 23-36.

Yamanaka, H., Moriguchi, T., Masuyama, N., Kusakabe, M., Hanafusa, H., Takada, R., Takada, S., and Nishida, E. (2002). JNK functions in the non-canonical Wnt pathway to regulate convergent extension movements in vertebrates. EMBO Rep. 3, 69-75.

Zhou, Y., Wang, Q., Evers, B. M., and Chung, D. H. (2005). Signal transduction pathways involved in oxidative stress-induced intestinal epithelial cell apoptosis. Pediatr. Res. 58, 1192-1197.

Conflict of Interest Statement: The authors declare that the research was conducted in the absence of any commercial or financial relationships that could be construed as a potential conflict of interest.

Received: 17 December 2010; accepted: 19 August 2011; published online: 13 September 2011.

Citation: Cheung $R$, Kelly $J$ and Macleod RJ (2011) Regulation of villin by Wnt5a/Ror2 signaling in human intestinal cells. Front. Physio. 2:58. doi: 10.3389/fphys.2011.00058

This article was submitted to Frontiers in Renal and Epithelial Physiology, a specialty of Frontiers in Physiology.

Copyright (C) 2011 Cheung, Kelly and Macleod. This is an open-access article subject to a non-exclusive license between the authors and Frontiers Media $S A$, which permits use, distribution and reproduction in other forums, provided the original authors and source are credited and other Frontiers conditions are complied with. 